\title{
PENILAIAN LAPORAN ARUS KAS UNTUK MENGUKUR KINERJA KOPERASI SIMPAN PINJAM PADA PAYU PERIODE 2013-2015
}

\author{
Putu Desy Gita Lavenia \\ Jurusan Akuntansi Program Diploma III, \\ Universitas Pendidikan Ganesha, Singaraja \\ desygita@gmail.com
}

\begin{abstract}
Abstrak
Penelitian ini bertujuan untuk mengetahui kinerja Koperasi Simpan Pinjam Pada Payu dengan menilai kinerja dari laporan arus kas pada periode 2013-2015.Subyek dari penelitian ini adalah Koperasi Simpan Pinjam Pada Payu, sedangkan obyek dari penelitian ini adalah penilaian laporan arus kas untuk mengukur kinerja.Metode pengumpulan data yang digunakan adalah dengan wawancara dan dokumentasi.

Adapun hasil yang di dapat dari penelitian ini menunjukkan (1) Arus kas pada tahun 2013 mengalami penurunan sebesar (Rp 138.014.090), Arus kas pada tahun 2014 mengalami penurunan sebesar Rp 2.532.748).Pada tahun 2015 arus kas mengalami peningkatan sebesar (Rp 71.350.151),(2) Berdasarkan laporan arus kas tahun 2013 sampai 2015 dapat dinilai kinerja dari Koperasi Simpan Pinjam Pada Payu. Dimana kinerja dari koperasi ini dinilai dari laporan arus kas pada tahun 2013 sampai tahun 2015 adalah kurang baik, karena kas cenderung mengalami naik turun setiap tahunnya dan kurangnya konsitensi dalam menetapkan maksimal pengeluaran dana, sehingga terjadi aliran kas yang negatif.
\end{abstract}

Kata kunci : Penilaian, Laporan Arus Kas,Koperasi Simpan Pinjam

Abstract
This study aims to determine the performance of Credit Unions In Breast to assess the performance of the cash flow statement in the period 2013-2015. The subjects of this study is the Credit Unions In Breast, whereas the object of this study is the assessment of cash flows for measuring kinerja.Metode used data collection is by interview and documentation, while the analysis technique used is quantitative data analysis techniques.

The results obtained from this study indicate (1) The cash flow in 2013 decreased by (USD 138014090 ) where the operating and investment activities resulted in a negative cash flow, and financing activities resulted in a positive cash flow. Cash flow in 2014 decreased by USD 2,532,748, of which the operating activities generate a positive cash flow and investing and financing activities resulted in a negative cash flow. In 2015, cash flow increased by (USD 71,350,151), of which operations and investments generate positive cash flow and financing activities resulted in a negative cash flow. (2) Based on the statement of cash flows in 2013 and 2015 can be assessed the performance of the Credit Unions On Breast. Where the performance of the cooperative is assessed from the statement of cash flows in the year 2013 to 2015 is not good, because the cash tends to go up and down every year, and the lack of consistency in setting a maximum expenditure of funds, resulting in a negative cash flow. Can be seen from a comparison of cash in 2013-2014 decreased by Rp $140546839-101.84 \%$ and the percentage of cash in cash from 2014 to 2015 increased by (USD $73,882,899)$ by the percentage of $-32.10 \%$. Decrease in cash can be caused also because of the amount of cash outlay used is greater than the amount of cash receipts exist.

Keywords: Assessment, Statement of Cash Flows, and Credit Unions

\section{Pendahuluan}

Koperasi merupakan suatu badan usaha yang berbadan hukum dan berlandaskan berdasarkan asas kekeluargaan dan juga asas demokrasi ekonomi serta terdiri dari beberapa anggota didalamnya. Menurut Undang-Undang Republik Indonesia No. 25 Tahun 
1992 tentang perkoperasian menegaskan bahwa "Koperasi Indonesia adalah badan usaha yang beranggotakan orang seorang atau badan hukum koperasi dengan melandaskan kegiatannya berdasarkan prinsip koperasi sekaligus sebagai gerakan ekonomi rakyat yang berdasarkan asas kekeluargaan. Koperasi memiliki sedikit perbedaan dibanding badan usaha lain seperti PT, CV, Firma atau Yayasan, di mana koperasi lebih terlihat dari sisi kekeluargaan dan gotong royong untuk saling membantu anggotanya demi kesejahteraan bersama sesuai prinsip dasar koperasi yang diatur dalam UU No 17 Tahun 2012. Dalam menjalankan usahanya, koperasi terdiri dari pengurus dan pengawas yang dipilih dalam Rapat Anggota. Pengurus inilah yang akan menjalankan usaha koperasi demi kesejahteraan anggotanya.

Terdapat banyak jenis-jenis koperasi, salah satunya adalah Koperasi Simpan Pinjam. Koperasi Simpan Pinjam merupakan lembaga keuangan bukan bank yang usahanya di bidang perkreditan, yaitu menerima simpanan uang dan meminjamkan modal pada anggota. Dalam menjalankan usahanya, koperasi simpan pinjam membutuhkan dana-dana, dana-dana tersebut bisa dalam bentuk uang yang masuk dalam kategori hutang atau ekuitas atau kekayaan bersih. Dari keseluruhan sumber dana tersebut, sumber dana utama adalah simpanan. Menurut PP 9 Tahun 1995 simpanan adalah dana yang dipercayakan oleh anggota, calon anggota, koperasi lain dan atau anggotanya kepada koperasi simpan pinjam dalam bentuk tabungan dan simpanan koperasi berjangka.

Koperasi Simpan Pinjam merupakan lembaga keuangan non Bank yang memiliki peranan sangat penting dalam hal pembangunan ekonomi, khususnya di Indonesia. Jadi koperasi simpan pinjam harus memiliki kinerja yang baik dalam melayani masyarakat dan mengelola dana yang ada dengan baik, mengingat saat ini tidak sedikit koperasi simpan pinjam yang kurang maju dan terancam bangkrut. Contohnya saja yang sudah terjadi pada Koperasi TRI JAYA merupakan salah satu koperasi yang berada di daerah Kabupaten Buleleng yang kini telah mengalami kebangkrutan. Kebangkrutan pada koperasi bisa saja terjadi karena kurangnya tanggungjawab dan sikap jujur pengurus koperasi. Tidak hanya itu, faktor yang bisa menjadikan koperasi bangkrut dan tidak bisa berkembang lagi adalah kurangnya kemampuan kinerja pegawai, ketidakmampuan koperasi dalam mengelola dana yang ada, selain itu juga kurangnya pengawasan manajemen pada koperasi. Pengawasan yang dimaksud adalah bagaimana posisi keuangan koperasi yang dapat dilihat pada laporan keuangannya. Laporan keuangan merupakan catatan informasi keuangan suatu perusahaan pada suatu periode teretentu yang dapat digunakan untuk menggambarkan kinerja perusahaan. Salah satu bentuk informasi keuangan adalah laporan arus kas, dimana pada laporan arus kas akan menggambarkan laporan sumber-sumber utama penerimaan kas serta pengeluaran atau pembayaran kas pada periode tertentu. Laporan keuangan yang terdapat di koperasi adalah neraca, laporan sisa hasil usaha, laporan ekonomi promosi anggota, laporan arus kas, dan catatan atas laporan keuangan.

Pada laporan arus kas koperasi, pihak manajemen dapat memperkirakan jumlah biaya operasional yang akan dikeluarkan. Pada laporan arus kas akan terlihat juga pengaruh kas dari kegiatan operasi, kegiatan investasi, dan kegiatan pembiayaan/pendanaan serta, kenaikan atau penurunan bersih dalam kas koperasi simpan pinjam. Namun tidak semua koperasi memiliki laporan arus kas, melainkan hanya laporan neraca dan laporan sisa hasil usaha saja. Dengan ketidaktersediaan laporan arus kas pada koperasi, maka koperasi tidak bisa memperkirakan berapa dana kas yang masuk dan berapa dana yang keluar, tidak hanya itu pihak-pihak yang berkepentingan juga tidak bisa menilai bagaimana kinerja koperasi dan tidak dapat mengetahui posisi keuangan pada koperasi apakah SHU yang di dapat mengalami kenaikan atau penurunan. Jadi dengan adanya laporan arus kas, pihak pengawas dan anggota dapat menilai bagamaina kinerja dan kebijakan manajemen pada koperasi simpan pinjam dalam mengelola sumber dana yang ada dan melaporkannya dalam laporan arus kas.

Berdasarkan latar belakang tersebut, maka dapat dirumuskan masalah yaitu,“ Bagaimana laporan arus kas pada Koperasi Simpan Pinjam Pada Payu periode 2013-2015 
?, (2) Bagaimana hasil penilaian kinerja Koperasi Simpan Pinjam Pada Payu dilihat dari laporan arus kas periode 2013-2015 ?"

\section{Metode Penelitian}

Pada metode penelitian, hal pertama yang harus dilakukan adalah menentukan lokasi penelitian dimana lokasi yang dipilih peneliti adalah pada Koperasi Simpan Pinjam Pada Payu yang beralamat di Jalan Pulau Komodo XX Banyuning Singaraja. Setelah lokasi penelitian ditentukan barulah peneliti melihat hal-hal apa saja yang terjadi pada Koperasi Simpan Pinjam Pada Payu yang berkaitan dengan laporan arus kas untuk mengukur kinerja koperasi. Kemudian peneliti dapat merumuskan masalah dari penelitian ini. Selanjutnya peneliti membuat kajian teori dimana dari kajian teori inilah peneliti dapat mengetahui datadata apa sajakah yang dibutuhkan. Data yang digunakan dalam penelitian ini adalah data kuantitatif yang berasal dari catatan mengenai laporan arus kas. Data yang diperoleh kemudian dianalisis dengan analisis deskriptif kuantitaif. Dari pengolahan data tersebut peneliti dapat menarik hasil penelitian yang selanjutnya dapat ditarik kesipulan mengenai penilaian laporan arus kas untuk mengukur kinerja koperasi.

\section{Hasil dan Pembahasan}

Dalam menilai laporan arus kas, digunakan metode horizontal yaitu metode analisis dengan membandingkan laporan arus periode 2013 dengan 2014 dan laporan arus kas periode 2014 dengan 2015.

Dari perbandingan laporan arus kas 2013-2014 dan 2014-2015 maka dapat dijelaskan sebagai berikut :

A. KEGIATAN OPERASI

Dalam kegiatan operasi terjadi penurunan kas sebesar Rp 1.769.016.123 dengan persentase sebesar 120,17\% dimana pada tahun 2013 kas kegiatan operasi sebesar (Rp 1.472.060.932) sedangkan pada tahun 2014 kas kegiatan operasi sebesar Rp 296.955.191. Penurunan kas terjadi karena penerimaan kas lebih kecil dari pada pengeluaran kas. Penurunan kas bersih kegiatan operasi dipengaruhi oleh pos-pos berikut :

1. Penerimaan Kas Operasi

a. Laba sisa hasil usaha mengalami kenaikan sebesar ( $\mathrm{Rp} 11.053 .738)$ dengan persentase sebesar $-86,83 \%$, dimana pada tahun 2013 labanya sebesar $\mathrm{Rp}$ 12.729.993 sedangkan pada tahun 2014 turun menjadi Rp 1.676.255.

b. Penyusutan aset tidak lancar mengalami penurunan sebesar (Rp 8.134.022) dengan persentase sebesar $-75,80 \%$, dimana pada tahun 2013 penyusutan sebesar Rp 10.730.772 dan pada tahun 2014 turun menjadi Rp 2.596.750.

c. Pendapatan Bunga Yang Masih Harus Diterima mengalami kenaikan sebesar Rp 38.850.262 dengan persentase 100\% dimana pada tahun 2013 sebesar Rp 0 menjadi Rp 38.850.262

d. Tabungan Wajib mengalami kenaikan sebesar (Rp 85.385.000) dengan persentase sebesar $-281,78 \%$ dimana pada tahun 2013 tabungan sebesar Rp 30.302.400 dan pada tahun 2014 menjadi (Rp 55.082.600).

e. Tabungan Sukarela mengalami penurunan sebesar ( $R p$ 232.220.652) dengan persentase sebesar $-87,15 \%$, dimana pada tahun 2013 sebesar $R p$ 266.462.706 dan pada tahun 2014 turun menjadi Rp 34.242.054.

f. Titipan mengalami penurunan sebesar Rp 31.052.240 dengan persentase sebesar $-178,81 \%$, dimana pada tahun 2013 sebesar Rp (17.366.267) dan pada tahun 2014 turun menjadi Rp 13.685.972.

g. Simpanan Berjangka mengalami penurunan sebesar Rp 242.081.400,00 dengan persentase sebesar 20,63\% dimana pada tahun 2013 jumlahnya sebesar ( Rp 126.987.400) dan pada tahun 2014 jumlahnya menjadi Rp 115.094.000. 
2. Pengeluaran Kas Operasi

a. Pinjaman Yang Diberikan mengalami penurunan sebesar Rp 1.676.757.395 dengan persentase sebesar $-110,92 \%$, dimana pada tahun 2013 sebesar (Rp 1.511.737.035) dan pada tahun 2014 menjadi Rp 165.020.360.

b. Cadangan Piutang Ragu-ragu mengalami kenaikan sebesar Rp 7.600.000,00 dengan persentase sebesar $84,44 \%$, dimana pada tahun 2013 sebesar $R p$ 9.000.000 dan pada tahun 2014 menjadi Rp 16.600.000.

c. Uang Muka Pajak mengalami penurunan sebesar Rp 10.268.100 dengan persentase sebesar $-100 \%$ dimana pada tahun 2013 sebesar (Rp 10.268.100) dan pada tahun 2014 menjadi Rp 0.

d. Beban Dibayar Dimuka mengalami penurunan sebesar Rp 103.819.700,00 dengan persentase sebesar $-72,80 \%$ dimana pada tahun 2013 sebesar (Rp 144.601.900) sedangkan pada tahun 2014 menjadi (Rp 40.782.200)

e. Biaya Yang Masih Harus Dibayar mengalami penurunan sebesar Rp 5.354.338 dengan persentase sebesar 100\% dimana pada tahun 2013 jumlahnya sebesar Rp 0 dan pada tahun 2014 menjadi 5.354.338.

f. Hutang Pajak mengalami penurunan sebesar Rp.10.562.300, denga persentase sebesar $-97,24 \%$, dengan jumlah keseluruhan pada tahun 2013 sebesar (Rp 10.862.300) dan pada tahun 2014 menjadi ( $R p$ 300.000)

B. KEGIATAN INVESTASI

Dalam kegiatan investasi terjadi penurunan kas sebesar Rp 12.468 .000 dengan persentase $-75,07 \%$, dimana harga peolehan tetap pada tahun 2013 sebesar (Rp 16.608.000) dan pada tahun 2014 turun menjadi Rp (4.140.000).

C. KEGIATAN PENDANAAN

a. Hutang KTA (BPD) mengalami penurunan sebesar Rp 830.277.779 dengan persentase sebesar $-95,83 \%$ dimana jumlah pada tahun 2013 sebesar Rp 910.833.341,00 dan pada tahun 2014 menjadi (Rp 866.388.893).

b. Hutang BPD mengalami kenaikan sebesar Rp 759.714 .443 dengan persentase sebesar $100 \%$ dimana pada tahun 2013 jumlahnya sebesar Rp 0 dan pada tahun 2014 menjadi Rp 759.714.443.

c. Hutang PUK-tel mengalami penurunan sebesar $\mathrm{Rp} 93.753 .600$ dengan persentase sebesar $-140,63 \%$ dimana pada tahun 2013 jumlahnya sebesar (Rp 66.668.200) dan pada tahun 2014 menjadi Rp 27.085.400.

d. Hutang Pihak Ke Tiga mengalami penurunan sebesar Rp 6.625.000,00 dengan persentase sebesar $-100 \%$ dimana pada tahun 2013 jumlahnya sebesar (Rp 6.625.000) dan pada tahun 2014 menjadi Rp 0

e. Simpanan Pokok mengalami kenaikan sebesar (Rp 500.000) dengan persentase sebesar 100\% dimana jumlahnya pada tahun 2013 sebesar Rp 0 dan pada tahun 2014 kenaikannya sebesar (Rp 500.000)

f. Simpanan Wajib mengalami penurunan sebesar (Rp 3.070.000) dengan persentase sebesar $-17,52 \%$ dimana jumlah pada tahun 2013 sebesar Rp 17.520.000 dan pada tahun 2014 penurunannya sebesar Rp 14.450.000.

g. Simpanan Khusus mengalami kenaikan sebesar (Rp 4.500.000) dengan persentase sebesar $100 \%$ dimana jumlahnya pada tahun 2013 sebesar Rp 0 dan kenaikan di tahun 2014 sebesar (Rp 4.500.000)

h. Nilai Kenaikan Modal mengalami kenaikan sebesar Rp 3.160.000 dengan persentase sebesar Rp 100\% dimana jumlahnya pada tahun 2013 sebesar Rp 0 dan kenaikan pada tahun 2014 sebesar Rp 3.160.000.

i. Cadangan mengalami penurunan sebesar $\mathrm{Rp} 1.183 .007$ dengan persentase sebesar 13,37\% dimana jumlahnya pada tahun 2013 sebesar Rp 8.847 .600 dan penurunannya pada tahun 2014 sebesar Rp 10.030.607.

Sementara itu dari hasil perbandingan laporan arus kas periode 2014-2015, dapat terlihat terjadi kenaikan kas sebesar (Rp 73.882.899) dengan persentase sebesar $-292,10 \%$ dimana kas pada tahun 2014 sebesar Rp 2.532.748 dan pada tahun 2015 naik sebesar (Rp 
71.350.151). Penurunan kas ini disebabkan oleh adanya perubahan kas pada masingmasing pos kegiatan. Perubahan-perubahan yang dimaksud adalah sebagai berikut :

A. KEGIATAN OPERASI

Dalam kegiatan operasi terjadi penurunan kas sebesar Rp 56.070 .639 dengan persentase sebesar 18,88\% dimana pada tahun 2014 kas kegiatan operasi sebesar Rp 296.955.191 sedangkan pada tahun 2015 kas kegiatan operasi sebesar Rp 3535.025830. Kenaiakn kas terjadi karena jumlah pengeluaran kas sesuai dengan penerimaan kas yang ada berikut :

1. Penerimaan Kas Operasi

a. Laba Bersih sisa hasil usaha mengalami kenaikan sebesar (Rp 18.249.368) dengan persentase sebesar $-12,70 \%$ dimana pada tahun 2014 labanya sebesar Rp 1.676.255 sedangkan pada tahun 2015 menjadi (Rp 16.573.112).

b. Penyusutan aset tidak lancar mengalami kenaikan sebesar $\mathrm{Rp} 6.190 .667$ dengan persentase sebesar $24,40 \%$ dimana pada tahun 2014 penyusutan sebesar Rp 2.596.750 dan pada tahun 2015 menjadi Rp 8.787.417.

c. Pendapatan Bunga Yang Masih Harus Diterima mengalami penurunan sebesar (Rp 38.850.262,00) dengan persentase $-100 \%$ dimana pada tahun 2014 sebesar Rp 38.850.262,00 menjadi Rp 0 pada tahun 2015.

d. Tabungan Wajib mengalami penurunan sebesar Rp 53.093.600 dengan persentase sebesar -96,39\% dimana pada tahun 2014 tabungan sebesar (Rp 55.082.600) dan pada tahun 2015 menjadi (Rp 1.989.000)

e. Tabungan Sukarela mengalami kenaikan sebesar Rp 136.674 .335 dengan persentase sebesar 30,14\% dimana pada tahun 2014 sebesar Rp 34.242.054 dan pada tahun 2015 menjadi Rp 170.916.389.

f. Titipan mengalami penurunan sebesar (Rp 22.506.994) dengan persentase sebesar $-164,45 \%$ dimana pada tahun 2014 sebesar Rp 13.685 .972 dan pada tahun 2015 menjadi (Rp 8.821.023).

g. Simpanan Berjangka mengalami kenaikan sebesar Rp 605.163.800 dengan persentase sebesar $525,80 \%$ dimana pada tahun 2014 jumlahnya sebesar Rp 115.094.000 dan pada tahun 2015 jumlahnya menjadi Rp 720.257.800.

3. Pengeluaran Kas Operasi

g. Pinjaman Yang Diberikan mengalami kenaikan sebesar (Rp 677.097.460) dengan persentase sebesar -410,31 dimana pada tahun 2014 sebesar $R p$ 165.020.360 dan pada tahun 2015 menjadi (Rp 512.077.100).

h. Cadangan Piutang Ragu-ragu mengalami kenaikan sebesar Rp 3.691.800 dengan persentase sebesar $22,24 \%$ dimana pada tahun 2014 sebesar $R p$ 16.600.000 dan pada tahun 2015 menjadi Rp 20.291.800.

i. Beban Dibayar Dimuka mengalami penurunan sebesar Rp 14.492.000 dengan persentase sebesar -35,54\% dimana pada tahun 2014 sebesar (Rp 40.782.200) sedangkan pada tahun 2015 menjadi (Rp 26.290.200).

j. Biaya Yang Masih Harus Dibayar mengalami penurunan sebesar Rp 5.354.338,00 dengan persentase sebesar $-100 \%$ dimana pada tahun 2014 jumlahnya sebesar $\mathrm{Rp} 5.354 .338,00$ dan pada tahun 2015 menjadi $\mathrm{Rp} 0$.

\section{B. KEGIATAN INVESTASI}

Harga perolehan aktiva tetap mengalami penurunan sebesar $\mathrm{Rp} 4.140 .000$ dengan persentase sebesar $-100 \%$.

\section{KEGIATAN PENDANAAN}

Dalam kegiatan pendanaan dapat dilihat terjadi kenaikan sebesar ( $R p$ 134.093.538) dengan presentase sebesar 44,19\% dimana pada tahun 2014 jumlah arus kas dalam kegiatan pendanaan sebesar (Rp 290.282.443) sedangkan pada tahun 2015 kenaikan sebesar (Rp 424.375.981) Kenaikan kas pada kegiatan pendanaan dipengaruhi oleh pospos berikut ini : 
1. Hutang KTA (BPD) mengalami penurunan sebesar $\mathrm{Rp} 830.277 .779$ dengan persentase sebesar $-95,83 \%$ dimana jumlah pada tahun 2014 sebesar Rp 866.388.893 dan pada tahun 2015 menjadi Rp 36.111.114.

2. Hutang BPD mengalami penurunan sebesar ( $R p$ 975.345.543) dengan persentase sebesar $-128,38 \%$ dimana pada tahun 2014 jumlahnya sebesar Rp 759.714 .443 dan pada tahun 2015 menjadi (Rp 215.631.100).

3. Hutang PUK-tel mengalami kenaikan sebesar (Rp 56.73.400) dengan persentase sebesar $-209,61 \%$ dimana pada tahun 2014 jumlahnya sebesar Rp 27.085 .400 dan pada tahun 2015 menjadi (Rp 29.688.00)

4. Simpanan Pokok mengalami kenaikan sebesar $\mathrm{Rp} 3.500 .000,00$ dengan persentase sebesar 700\% dimana jumlahnya pada tahun 2014 sebesar Rp 500.000 dan pada tahun 2015 kenaikannya sebesar (Rp 3.000.000).

5. Simpanan Wajib mengalami kenaikan sebesar Rp 13.630.000 dengan persentase sebesar 94,33\% dimana jumlah pada tahun 2014 sebesar Rp 14.450 .000 dan pada tahun 2015 kenaikannya sebesar Rp 28.080.000.

6. Simpanan Khusus mengalami kenaikan sebesar Rp 31.500.000,00 dengan persentase sebesar $-700 \%$ dimana jumlahnya pada tahun 2014 sebesar (Rp 4.500.000) dan kenaikan di tahun 2015 sebesar Rp 27.000.000.

7. Nilai Kenaikan Modal mengalami kenaikan sebesar Rp 25.180.000,00 dengan persentase sebesar 596,84\% dimana jumlahnya pada tahun 2014 sebesar Rp 3.160.000 dan kenaikan pada tahun 2015 sebesar Rp 22.020.000.

8. Cadangan mengalami penurunan sebesar $\mathrm{Rp} 257.626$ dengan persentase sebesar $2,57 \%$ dimana jumlahnya pada tahun 2014 sebesar $R p 10.030 .607$ dan penurunannya pada tahun 2015 sebesar Rp 10.288.233.

Berdasarkan hasil perbandingan laporan arus kas Koperasi Simpan Pinjam Pada Payu periode 2013-2015 pada kas dan setara kas akhir tahun mengalami kenaikan dan penurunan. Dimana pada perbandingan arus kas tahun 2013 dan 2014 kas dan setara kas mengalami penurunan, dimana tahun 2013 besar kas dan setara kasnya (Rp 138.014.090) sedangkan pada tahun 2014 kas dan setara kasnya sebesar Rp 2.532 .748 sehingga menghasilkan selisih Rp 140.546 .839 dengan persentase sebesar $-101,84 \%$. Pada perbandingan arus kas 2014-2015 kas dan setara kas mengalami kenaikan, dimana pada tahun 2014 kas dan setara kas sebesar Rp 2.532 .748 sedangkan pada tahun 2015 kas dan setara kasnya sebesar (Rp 71.350.151) sehingga menghasilkan selisih (Rp 73.882.899).

\section{Simpulan dan Saran}

Adapun kesimpulan yang dari penelitian ini adalah (1) Arus kas pada tahun 2013 mengalami penurunan sebesar (Rp 138.014.090) dimana kegiatan operasi dan investasi menghasilkan aliran kas negatif, dan kegiatan pendanaan menghasilkan aliran kas positif. Arus kas pada tahun 2014 mengalami penurunan sebesar Rp 2.532.748, dimana kegiatan operasi menghasilkan aliran kas positif dan kegiatan investasi dan pendanaan menghasilkan aliran kas negatif. Pada tahun 2015 arus kas mengalami peningkatan sebesar (Rp 71.350.151), dimana kegiatan operasi dan investasi menghasilkan aliran kas positif dan kegiatan pendanaan menghasilkan aliran kas negatif, (2) Berdasarkan laporan arus kas tahun 2013 sampai 2015 dapat dinilai kinerja dari Koperasi Simpan Pinjam Pada Payu. Dimana kinerja dari koperasi ini dinilai dari laporan arus kas pada tahun 2013 sampai tahun 2015 adalah kurang baik, karena kas cenderung mengalami naik turun setiap tahunnya dan kurangnya konsitensi dalam menetapkan maksimal pengeluaran dana, sehingga terjadi aliran kas yang negatif. Dapat dilihat dari perbandingan kas tahun 20132014 mengalami penurunan sebesar Rp 140.546.839 dengan persentase $-101,84 \%$ dan kas pada tahun 2014-2015 kas mengalami kenaikan sebesar (Rp 73.882.899) dengan persentase $-32,10 \%$. Penurunan kas ini dapat disebabkan juga karena jumlah pengeluaran kas yang digunakan lebih besar dari jumlah penerimaan kas yang ada. 
Sedangkan saran yang dapat disampaikan yaitu, (1) Koperasi Simpan Pinjam Pada Payu bisa menyampaikan dan menyajikan laporan arus kas pada saat RAT, tidak harus menunggu dari pihak auditor untuk bisa membuat laporan arus kas. Jadi saat RAT diadakan, pihak anggota bisa melihat posisi keuangan setiap tahun, dan bisa menilai langsung bagaimana pihak pengurus koperasi dalam mengelola kas yang masuk dan kas yang keluar, (2) Diharapkan dari hasil laporan arus kas setiap tahunnya, koperasi bisa mengevaluasi kegiatan pemasukan dan pengeluaran kas agar bisa lebih bijak dalam menggunakan dana yang ada dan memperkiran penggunaan dana pada tahun berikutnya agara tidak terjadi penurunan kas, dan diharapkan kas dan setara kas tahun ini bisa meningkat dibandingkan tahun sebelumnya.

\section{DAFTAR PUSTAKA}

Dhariyanto, 2010. "Penegertian Koperasi Menurut UUD No 25 Tahun 1992". (diakses tanggal 5 Maret 2016)

Sumberpanganpasuruan,2009. "Jenis-jenis Koperasi Di Indonesia". Tersedia pada https://sumberpanganpasuruan.wordpress.com/tag. (diakses tanggal 5 Maret 2016)

Ranto, 2012. "Sejarah Beridirinya Koperasi Di Indonesia". Tersedia pada https://sumberpanganpasuruan.wordpress.com/tag.

Imroatul, 2013. "Persaingan Lembaga Keuangan Bank dan Koperasi Simpan (diakses tanggal 8 Maret 2016)

Sejahterea, 2013. "Tujuan dan Fungsi Koperasi Simpan Pinjam". Tersedia pada 9 Maret 2016)

Landasan Teori, 2015. "Pengertian Penilaian Kinerja Pegawai dan Karyawan Perusahaan Definisi, Tujuan, Manfaat, dan Prinsip". Tersedia pada Maret 2016)

Peraturan Pemerintah, 2010. "PP 71 Tahun 2010 tentang Standar Akuntansi Pemerintah". http://inspektorat.kulonprogokab.go.id/article-1057-pp (diakses tanggal 14 Maret 2016)

Rudianto, 2010. "Akuntansi Koperasi Konsep Dan Teknik Penyusunan Laporan Keuangan Edisi ke-2. Jakarta: Penerbit Erlangga.

Kadek Yudiarta, 2013. "Analisis Laporan Keuangan Arus Kas Pada Lembaga Perkreditan Desa Pakraman Penglatan periode 2013-2014". Tugas Akhir (tidak diterbitkan). Jurusan Akuntansi Program Diploma III, Universitas Pendidikan Ganesha, Singaraja

Ida Bagus Ary Perdana, 2013. "Analisis Laporan Keuangan Arus Kas pada Koperasi Pegawai- Republik Indonesia "SETIA BUDHI" Periode 2010-2012". Tugas Akhir (tidak diterbitkan). Jurusan Akuntansi Program Diploma III UniversitasPendidikan Ganesha Singaraja Tersedia pada https://dhariyanto.wordpress.com/2010/12/22/

http://rantonet.blogspot.co.id/2012/11/.(diakses tanggal 6 Maret 2016)

http://kospin-sejahterea.blogspot.co.id/2013/02/.html (diakses tanggal 6 Maret 2016)

http://imroatul.blogspot.co.id/2013/04/.html (diakses tanggal 6 Maret 2016)

http://hedisasrawan.blogspot.co.id/2013/06/.html. (diakses tanggal 6 Maret 2016)

http://www.landasanteori.com/2015/10/.html (diakses tangaal 10 Maret 2016-03-06) 